\title{
Taxonomy and geographic distribution of potential toxic cyanobacterial strains in Morocco
}

\author{
M. Loudiki ${ }^{1}$ \\ B. Oudra ${ }^{1}$ \\ B Sabour ${ }^{1}$ \\ B. Sbiyyaa ${ }^{1}$ \\ V. Vasconcelos ${ }^{2}$
}

Keywords : Cyanobacteria, blooms, taxonomy, toxicity, distribution, Morocco.

In Morocco, poisoning events of fish, aquatic birds and livestock have been observed in some reservoirs and shallow lakes. In all cases, the reasons for animal mortality reasons have not been confirmed and the toxic cyanobacteria strains that were abundant in these water bodies have been suggested as their cause. Since 1994, the authors started taxonomic, ecological and toxicological studies by collecting samples from various lakes reservoirs and ponds. The results show that more than 18 out of 26 lakes reservoirs used for human water supply contained at least one species of planktonic cyanobacteria, where the genus Microcystis was dominant (Microcystis aeruginosa f. aeruginosa, M. aeruginosa f. flos-aquae, M. ichthyoblabe, M. pulverea f. delicatissima) and was associated with Oscillatoria, Planktothrix, Anabaena, Aphanizomenon, Phormidium and other genera. Taxonomic studies shows that among more than 150 cyanobacteria taxa identified in Moroccan freshwater ecosystems, 35 are potentially toxic. For several species, the toxicity of both natural blooms and isolated strains lyophilized material was confirmed by mouse bioassay and the microcystins content evaluated by the Enzyme-linked immunosorbent assay (ELISA). A map of geographic distribution of Microcystis strains inventoried in moroccan water bodies is presented.

\section{Taxonomie et distribution géographique des Cyanobactéries potentiellement toxiques au Maroc}

Mots-clés : Cyanobactéries, blooms, taxonomie, toxicité, distribution, Maroc.

Les causes exactes des cas d'intoxications de poissons, d'oiseaux aquatiques et de bétail, souvent observés dans quelques réservoirs et lacs peu profonds du Maroc, n'ont pas été définitivement établies. Les cyanobactéries qui prolifèrent régulièrement dans les plans d'eau concernés ont été cependant largement suspectés. Les études taxonomiques, écologiques et toxicologiques menées depuis 1994 sur plusieurs lacs de barrages montrent que parmi les 26 lacs utilisés pour l'approvisionnement en eau potable, 18 contiennent au moins une espèce de cyanobactérie potentiellement toxique et le genre Microcystis est largement dominant (Microcystis aeruginosa f. aeruginosa, M. aeruginosa f. flos-aquae, M. ichthyoblabe, M. pulverea f. delicatissima). Parmi 150 taxons de cyanobactéries inventoriés dans divers plans d'eau du Maroc, 35 sont répertoriés comme étant potentiellement toxiques. Pour certaines espèces, la toxicité des extraits du matériel algal lyophilisé à partir des blooms naturels ou des souches isolées a été confirmée par le test souris et les microcystines quantifiées par la technique d'analyse ELISA. Au terme de cette étude une carte de distribution géographique des souches de Microcystis potentiellement toxiques est proposée.

\footnotetext{
1. Faculty of Sciences Semlalia, P. Box 2390, Department of Biology, 40000 Marrakesh, Morocco.

E-mail : loudiki@ucam.ac.ma. Corresponding author.

2. Faculdade de Ciências do Porto, Departamento de Zoologia e Antropologia. Lab. Ecotoxicologia, 4050 Porto and CIMAR, Campus Agrario de Vairao, 4480 Vila do Conde, Portugal.
} 


\section{Introduction}

In order to reach its ever-increasing water requirements, Morocco has now an important infrastructure of dams (More than 90 reservoirs with a storage capacity of 14 billion $\mathrm{m} 3$ ). Actually, surface waters represent more than $70 \%$ of water supply, partly provided by 26 dams some of them devoted only to the human use.

The recent studies of many moroccan reservoirs showed their rapid eutrophication due to high nutrient loads and semi-arid climate conditions (Derraz 1995, Alaoui et al 1996, Mouhri et al 1999, Cherifi \& Loudi$\mathrm{ki}, 1999)$. The main eutrophication symptom is the rapid growth of algae especially cyanobacteria which usually forms heavy waterblooms. The sanitary risks and the effects of these blooms on water quality are now well known particularly in countries where drinking water reservoirs are contaminated by toxic cyanobacteria.

In Morocco, toxic cyanobacteria blooms are common in some water bodies used for recreational and / or drinking water reservoirs. Poisoning events of fish, aquatic birds and livestock have been observed during late summer in some moroccan reservoirs and natural ponds (ONEP 1996). But in all cases, the animal mortality reasons have not been confirmed in spite of the fact that both the oxygen low concentrations and particularly the abundant cyanobacteria strains in these water bodies have been registered. In order to establish a screening of potential toxic cyanobacterial strains in Morocco and get data about toxic cyanobacteria and their potential sanitary risks in some reservoirs and shallow lakes, a research program is carried out in the laboratory of Phycology, Faculty of Sciences Semlalia, Marrakesh in collaboration with other national and international partners.

The taxonomic, ecological and toxicological studies of cyanobacteria were undertaken since 1994 by collecting environmental samples and producing isolated strains in laboratory.

This paper provides a first screening of the potential toxic strains of cyanobacteria as well as their geographical distribution in some moroccan waterbodies. Furthermore, other data about ecological characteristics and toxicity of some collected Microcystis natural blooms and isolated strains are presented.

\section{Material and methods}

The study of phytoplankton and sampling of cyanobacterial blooms were undertaken since 1994 in va- rious freshwater reservoirs and natural lakes of Morocco. The set of 42 natural samples of planktonic cyanobacteria species was studied under the light microscope. Cyanobacteria bloom samples and isolated strains were observed, measured and identified by morphology-based taxonomy using the systems of Starmach (1966), Komarek \& Anagnostidis (1986) and Anagnostidis \& Komarek (1988).

In order to examine the pluriannual dynamics and the importance of cyanobacterial biomass in the phytoplankton communities and to describe the relation between environmental factors and cyanobacterial growth, a short term survey of the waterblooms was done over several years in two lake-reservoirs Lalla Takerkoust (Loudiki et al. 1997, Oudra et al. 1998) and Oued Mellah (Sabour et al. 2002). In these reservoirs, water stock is used for irrigation, watering of livestock, recreational activities, fisheries and public water supply.

To assess the toxicity of cyanobacterial, natural blooms samples were concentrated with a $27 \mu \mathrm{m}$ mesh plankton net, freeze-dried and stored frozen at $-20^{\circ} \mathrm{C}$. The isolation and culture of cyanobacterial strains was made on Z8 medium under laboratory controlled conditions (Kotai 1972). The toxicity of cyanobacterium lyophilized material was confirmed by mouse bioassay according methods previously described in Oudra et al. (1998). The amount of total microcystins was determined by the Enzyme-linked immunosorbent assay (ELISA) using Millipore Microplate Kit (EnviroGard ${ }^{\circledR}$ Microcystins Plate Kit) according to methods described by An \& Carmichael (1994).

\section{Results and discussion}

The sampling and taxonomic study of cyanobacteria species in various Moroccan stagnant waters, associated with inventory investigations of previous work, enabled us to establish a first screening of planktonic potentially toxic cyanobacteria strains. The results show that among the 150 taxa of cyanobacteria catalogued until now in moroccan freshwater bodies (Gayral 1954, Loudiki 1990), 35 are frequently quoted by the literature as being potentially toxic (Table 1). Among the inventoried cyanobacteria genera Anabaena, Oscillatoria, Planktothrix, Aphanizomenon, Chroococcus and Phormidium, Microcystis constitutes the most widespread one. Regularly present in many aquatic environments of Morocco, Microcystis often forms spectacular blooms in certain eutrophic water reservoirs. Microcystis blooms were reported for the first time in natural ponds (Gayral 1954) and in El Kansera and 
Table 1. Distribution of potential toxic cyanobacterial strains in Moroccan reservoirs and natural ponds.

Tableau 1. Distribution des souches de cyanobactéries potentiellement toxiques dans les lacs de barrage et les plans d'eau naturels du Maroc. Reservoirs : AF = Allal ElFassi $; \mathrm{AM}=\mathrm{Al}$ Massira $; \mathrm{DA}=$ Daourat $; \mathrm{EK}=$ ElKansera $; \mathrm{HI}=$ Hassan I $; \mathrm{IM}=\mathrm{Imfout} ; \mathrm{LT}=\mathrm{Lalla}$ Takerkoust ; ME = Mansour Eddahbi $;$ OE = Oued El Makhazine $; \mathrm{OM}=$ Oued Mellah $; \mathrm{SA}=$ Sahela $; \mathrm{SMBA}=$ Sidi Med Ben Abdellah ; YT = Youssef Ben Tachfine ; IB = Ibn Battouta ; MV = Mohamed V; AB = Abdelmoumen ; MK = Mohamed ben abdelkrim Khattabi ; II = Idriss I Natural ponds : AA = Aguelmane Azigza $; \mathrm{ASA}=$ Aguelmane Sidi Ali $; \mathrm{TI}=$ Tigalmamine $; \mathrm{DE}=$ Dayèt Erroumi $; \mathrm{SB}=\mathrm{Sidi}$ Bou Ghaba References : 1- Bouhaddioui (1997) ; 2-Derraz (1995) and ONEP (1996) ; 3- Loudiki (1990) ; 4- Oudra et al.(1998, 2001) ; 5- ONEP (1996) ; 6- Ghedda (1997) ; 7- Gayral (1954)

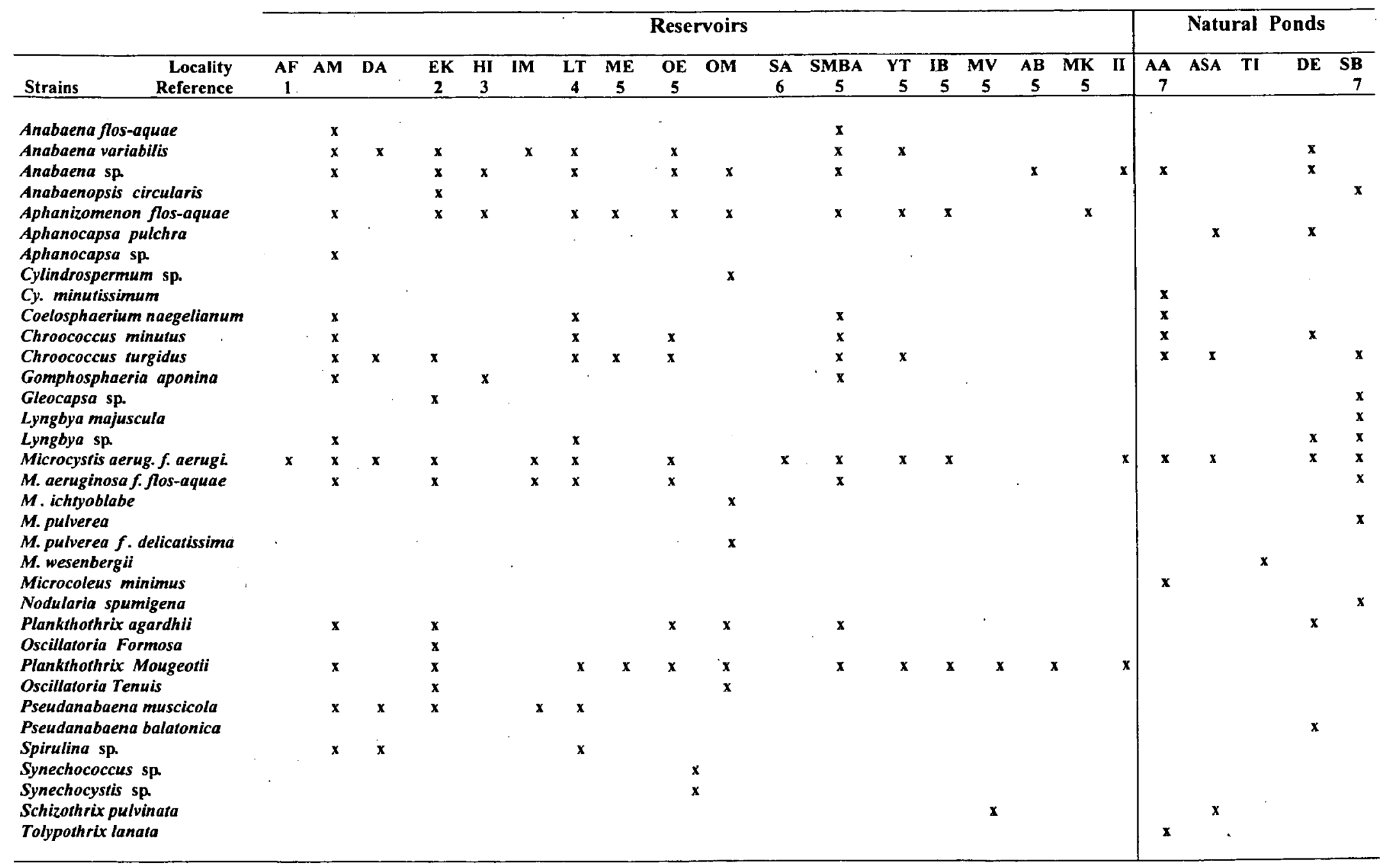

SMBA reservoirs (Gayral 1954, Abouzaid et al. 1984) and then in other eutrophic dams (Loudiki 1995, Derraz 1995, Sbiyyaa et al. 1998, Oudra et al. 1998). Actually, several Microcystis species cause regularly blooms during the summer and autumn in different drinking and/or recreational water reservoirs. More than 18 out of 26 lakes reservoirs used for human water supply contained at least one species of planktonic cyanobacteria, where the genus Microcystis was dominant (Table 1). The first recorded Microcystis species were reported in Middle Atlas natural lakes and El Kansera reservoir by Gayral (1954). Three taxa of $\mathrm{Mi}$ crocystis were identified : Microcystis aeruginosa Kütz., M. flos-aquae (Wittr.) Kirschn. and M. pulverea (Wood) Forti.
For a better understanding of the taxonomic entities of each species of the bloom-forming Microcystis, we collected samples from different reservoirs, natural lakes and ponds. The identification of the materials samples showed that at least six taxa of Microcystis are present in Morocco : Microcystis aeruginosa, f. aeruginosa Kütz., M. aeruginosa,. f. flos-aquae (Wittr.) Elenkin, $M$. ichthyoblabe, $M$. wesenbergii Kom., $M$. pulvere a and $M$. pulverea f. delicatissima (West) Elenkin (Table 1). Among the five Microcystis taxa, two species were for the first time recorded in Morocco : Microcystis wesenbergii which was identified at Tigalmamine natural lake (Middle Atlas) in October 1998 and Microcystis ichthyoblabe which was identified at Oued Mellah brackish and hypertrophic reservoir in 

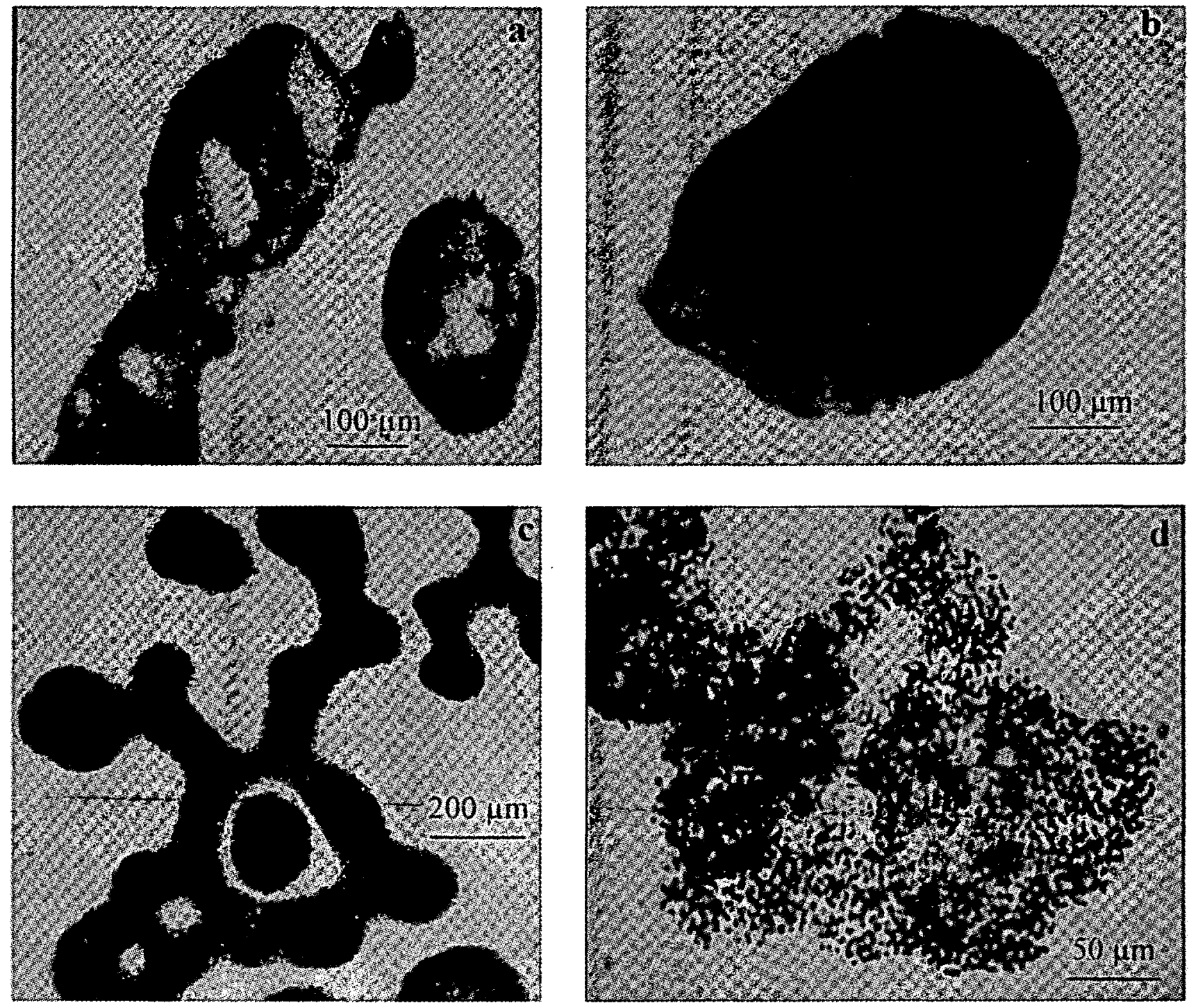

Plate 1. Light microscopy photographs of four Microcystis species : a) M. wesenbergii Kom. ; b) M. ichthyoblabe Kütz. ; c) M. aeruginosa f. aeruginosa Kütz. ; d) M. aeruginosa f. flos-aquae (Wittr.) Elenkin).

Planche 1. Photographies au microscope optique de quatre espèces de Microcystis : a) M. wesenbergii Kom. ; b) M. ichthyoblabe Kütz. ; c) M. aeruginosa f. aeruginosa Kütz. ; d) M. aeruginosa f. flos-aquae (Wittr.) Elenkin).

June 1999 (Plate 1). Some physico-chemical characteristics are given in table 2 for the two samples localities during Microcystis bloom-forming.

The colonies of $\mathbf{M}$. wesenbergii are generally spheric or irregularly lobbed. Small cells ( 3 to $4 \mu \mathrm{m}$ in diameter) are often gathered in one site of the colony's envelope and rich of gas vesicles. This explains the buoyancy of colonies on the lake surface as well as accumulation of scums especially in the sheltered areas. Whereas in $M$. ichthyoblabe, the colonies are rather soft, spongious and amorphous. The small cells ( 3 to $4 \mu \mathrm{m}$ in diameter), rich of gas vesicles, are generally more pressed in the borders of colony and sometimes groups of cells are localised in mass of scarcely distribute cells. These observations correspond to the description given by Watanabe (1996) of these two species.
The analysis of the geographical distribution of the Microcystis strains shows that this cyanobacteria presents a large spatial distribution and it proliferates in all water bodies of Morocco (Fig.1). This observation confirms on the one hand the ubiquist character of the Microcystis genus and on the other hand the high trophic state of the majority of freshwater systems. The Microcystis proliferation shows favourable heliothermic and nutritional conditions which exist in these areas.

The toxicological study of Microcystis blooms that were collected in Takerkoust, Almassira and Oued Mellah reservoirs shows a positive hepatotoxicity. This toxicity was quantified both by $\mathrm{LD}_{50}$ and total amount of microcystins determination (Table 3). The obtained results show a great annual (case of Takerkoust lake) and spatial variability of toxicity and mi- 


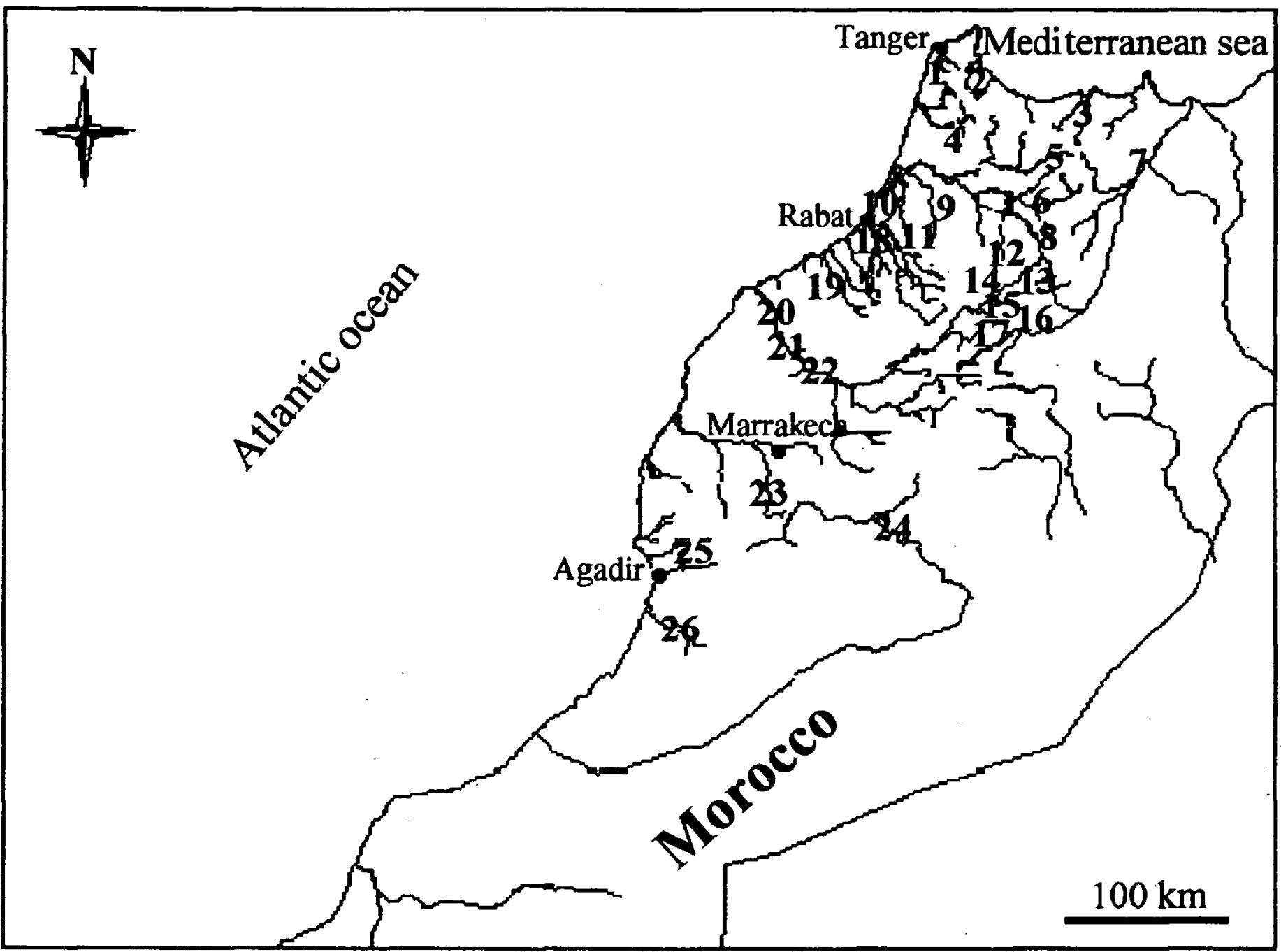

Fig. 1. Geographic localisation of some Moroccan reservoirs, natural lakes and ponds where Microcystis strains have been inventoried.

Reservoirs : 1- Ibn Battouta, 2- Smir, 3- M.B.A. Khettabi, 4- O. El Makhazine, 5- Sahela, 6- Idriss I, 7- Mohammed V, 8- Allal El Fassi, 9- El Kansera, 18- S.M.B. Abdellah, 19- Oued Mellah, 20- Daourat, 21- Imfout, 22- Al Massira, 23Lalla Takerkoust, 24- M. Eddahbi, 25- Abdelmoumen, 26- Y.B. Tachfine.

Natural lakes and ponds : 10- Sidi Boughaba, 11- Dayèt Erroumi, 12- Dayèt Aoua, 13- Dayèt Affourgah, 14- Dayèt Ifrah, 15- Aguelmane Azigza, 16- Aguelmnae Sidi Ali, 17- Tiguelmamine.

Fig. 1. Localisation géographique des lacs de barrage et plans d'eau naturels du Maroc où des souches de Microcystis ont été inventoriées.

Lacs de barrage : 1- Ibn Battouta, 2- Smir, 3- M.B.A. Khettabi, 4- O. El Makhazine, 5- Sahela, 6- Idriss I, 7- Mohammed V, 8- Allal El Fassi, 9- El Kansera, 18- S.M.B. Abdellah, 19- Oued Mellah, 20- Daourat, 21-Imfout, 22- Al Massira, 23- Lalla Takerkoust, 24- M. Eddahbi, 25- Abdelmoumen, 26- Y.B. Tachfine.

Plans d'eau naturels : 10- Sidi Boughaba, 11- Dayèt Erroumi, 12- Dayèt Aoua, 13- Dayèt Affourgah, 14- Dayèt Ifrah, 15- Aguelmane Azigza, 16- Aguelmane Sidi Ali, 17- Tiguelmamine.

crocystins content. The $M$. aeruginosa blooms of Takerkoust reservoir appear to be the most toxic ones with a $L_{50}$ ranged between 2 and $83 \mathrm{mg} . \mathrm{kg}^{-1}$ and microcystins content ranging also between 496 and 8800 $\mu \mathrm{g} . \mathrm{g}^{-1}$. The relationship between toxicity and amount of hepatotoxins have been previously discussed in $\mathrm{Ou}-$ dra et al. (2001). Whereas the extract of $M$. ichthyobla$b e$ that occurred in Oued Mellah lake are less toxic with $\mathrm{LD}_{50}$ up to $500 \mathrm{mg} \cdot \mathrm{kg}^{-1}$ and total microcystins of $0.79 \mu \mathrm{g} . \mathrm{g}^{-1}$. For the mesotrophic Almassira reservoir Microcystis bloom showed a medium toxicity level wi- th $\mathrm{LD}_{50}$ of $142 \mathrm{mg} \cdot \mathrm{kg}^{-1}$ and $0.37 \mu \mathrm{g} \cdot \mathrm{g}^{-1}$ of Microcystins. These results agree with literature data which made many important spatio-temporal fluctuations of $\mathrm{Mi}$ crocystis strains toxicity only expressed under well determined conditions (Carmichael 1996, Watanabe 1996).

The toxicological study of the Microcystis isolated strains cultivated on $\mathrm{Z} 8$ medium shows that all studied strains are also hepatotoxic. The spatio-temporal fluctuations remain less important than those observed for the natural blooms (Table 4). 
Table 2. Physical and chemical caracteristics of Oued Mellah and Tigalmamine lakes during Microcystis bloom-forming.

Tableau 2. Caractéristiques physiques et chimiques des lacs Oued Mellah et Tigalmamine en période de bloom à Microcystis.

\begin{tabular}{lll}
\hline & Oued Mellah reservoir & Tigalmamine lake \\
\hline Elevation $(\mathrm{m})$ & 92 & 1626 \\
Date of construction & $1928-1931$ & natural \\
Geographic situation & $33^{\circ} 30^{\prime} \mathrm{N}-07^{\circ} 20^{\prime} \mathrm{W}$ & $32^{\circ} 54^{\prime} \mathrm{N}-05^{\circ} 21^{\prime} \mathrm{W}$ \\
Substratum & Primary schist with triasic & Lower Lias dolomite \\
& saliferous clays & \\
Bioclimat & Semi-arid & Humide \\
Surface (ha) & 250 & 6 \\
Maximum depth $(\mathrm{m})$ & 9 & 16 \\
Total capacity $\left(\mathrm{Mm}^{3}\right)$ & 18 & \\
Water temperature $\left({ }^{\circ} \mathrm{C}\right)$ & 25 & 18 \\
pH & 8.3 & 8.6 \\
Dissolved oxygen $\left(\mathrm{mg} . \mathrm{L}^{-1}\right)$ & 8.1 & 8.8 \\
Conductivity $\left(\mu \mathrm{s} . \mathrm{cm}^{-1}\right)$ & 4000 & 794 \\
Chlorides $\left(\mathrm{g} . \mathrm{L}^{-1}\right)$ & 4.8 & 0.070 \\
Salinity $(\%)$ & $6.6-9$ & \\
\hline
\end{tabular}

The toxicity studied by mouse bioassay and ELISA analysis showed that the Microcystis natural blooms were generally more toxic than the culture of isolated strains. This difference was due to the cyanobacteria growth conditions (Watanabe \& Oishi 1985) or to the natural bloom contamination (containing also other cyanobacteria toxic species like Phormidium, Pseudanabaena, Oscillatoria, Planktothrix).

\section{Conclusion}

The results obtained during this study indicate that toxic cyanobacteria waterblooms may be common in many eutrophic reservoirs and natural ponds in Morocco. More than 18 out of 26 lake reservoirs used for human water supply contained at least one species of planktonic cyanobacteria, where the Microcystis species constitute the most widespread cyanobacterium. Most of the toxic blooms in drinking water reservoirs may represent an environmental health hazard to animals and humans.

\section{Acknowledgements}

This work was supported by PARS Project $\mathrm{N}^{\circ} 189$ Biology «Programme d'Appui à la Recherche Scientifique au Maroc» and the cooperation project CNCPRST- Morocco / ICCTI- Portugal. 
Table 3. Data on toxic Microcystis waterblooms in Morocco.

Tableau 3. Données sur les blooms toxiques au Maroc.

\begin{tabular}{|c|c|c|c|c|}
\hline Localities & $\begin{array}{c}\text { Waterblooms } \\
\text { Dominant species }\end{array}$ & $\begin{array}{l}\text { Sampling } \\
\text { Periods }\end{array}$ & $\begin{array}{l}\text { i.p. Mice bioassay } \\
\text { LD }_{50}(\mathrm{mg} / \mathrm{kg})\end{array}$ & $\begin{array}{l}\text { Average amount of } \\
\text { microcystins }(\mu \mathrm{g} / \mathrm{g})\end{array}$ \\
\hline \multirow[b]{2}{*}{$\begin{array}{l}\text { Lalla Takerkoust } \\
\text { reservoir }\end{array}$} & & 1994 & 4 & 710 \\
\hline & $\begin{array}{l}\text { Microcystis aeruginosa } \\
\text { f. aeruginosa }\end{array}$ & 1995 & 2 & 8800 \\
\hline \multirow[t]{4}{*}{ (Marrakech) } & associated with & 1996 & 20 & 2050 \\
\hline & $\begin{array}{l}\text { Microcystis aeruginosa } \\
\text { f. flos-aquae }\end{array}$ & 1997 & 73 & 1920 \\
\hline & & 1998 & 83 & 664 \\
\hline & & 1999 & 34 & 496 \\
\hline \multirow{3}{*}{$\begin{array}{l}\text { Almassira reservoir } \\
\text { ( Settat) }\end{array}$} & $\begin{array}{l}\text { Microcystis aeruginosa } \\
\text { f. aeruginosa }\end{array}$ & & & \\
\hline & associated with & 1999 & 142 & 0.37 \\
\hline & $\begin{array}{l}\text { Microcystis aeruginosa } \\
\text { f. flos-aquae }\end{array}$ & & & \\
\hline $\begin{array}{l}\text { Oued Mellah } \\
\text { Reservoir } \\
\text { (Casablanca) }\end{array}$ & Microcystis ichthyoblabe & 1999 & 502 & 0.79 \\
\hline
\end{tabular}

Table 4. Data on toxic Microcystis isolated strains in Morocco.

Tableau 4. Données sur les isolats de souches toxiques de Microcystis au Maroc.

\begin{tabular}{|c|c|c|c|c|}
\hline Localities & Cyanobacteria strains. & Dates of isolate & & $\begin{array}{l}\text { Average amount of } \\
\text { microcystins }(\mu \mathrm{g} / \mathrm{g})\end{array}$ \\
\hline & & & $\mathrm{LD}_{50}(\mathrm{mg} / \mathrm{Kg})$ & - \\
\hline \multirow{2}{*}{$\begin{array}{l}\text { Lalla Takerkoust } \\
\text { reservoir } \\
\text { (Marrakech) }\end{array}$} & $\begin{array}{l}\text { Microcystis aeruginosa } \\
\text { f. aeruginosa: }\end{array}$ & & $\cdots$ & $\cdots$ \\
\hline & $\begin{array}{l}\text {-FSMT-1 } \\
\text {-FSMT-2 }\end{array}$ & $\begin{array}{l}\text { July } 1994 \\
\text { August } 1997\end{array}$ & $\begin{array}{l}33 \\
\text { nd }\end{array}$ & $\begin{array}{l}650 \\
130\end{array}$ \\
\hline $\begin{array}{l}\text { Almassira reservoir } \\
\text { (Settat) }\end{array}$ & $\begin{array}{l}\text { Microcystis aeruginosa } \\
\text { f. aeruginosa: } \\
\text {-AM-1 } \\
\text {-AM-2 } \\
\text { - AM-3 }\end{array}$ & $\begin{array}{l}\text { September } 1997 \\
\text { July } 1998 \\
\text { November } 1999\end{array}$ & $\begin{array}{l}\text { nd } \\
238 \\
\text { nd }\end{array}$ & $\begin{array}{l}190 \\
\text { nd } \\
\text { nd }\end{array}$ \\
\hline $\begin{array}{l}\text { Deroua fish pond } \\
\text { (Béni-Mellal) }\end{array}$ & $\begin{array}{l}\text { Microcystis aeruginosa } \\
\text { f. aeruginosa: } \\
\text {-FP-1 } \\
\text {-FP-2 }\end{array}$ & $\begin{array}{l}\text { October } 1997 \\
\text { July } 1998\end{array}$ & $\begin{array}{l}\text { nd } \\
108\end{array}$ & $\begin{array}{c}\text { nd } \\
943.7 \\
\end{array}$ \\
\hline $\begin{array}{l}\text { Oued Mellah } \\
\text { reservoir } \\
\text { (Casablanca) }\end{array}$ & $\begin{array}{l}\text { Microcystis ichthyoblabe: } \\
\text {-OM-1 } \\
\text {-OM-2 } \\
\text {-OM-3 }\end{array}$ & $\begin{array}{l}\text { July } 1997 \\
\text { June } 1998 \\
\text { June } 1999\end{array}$ & $\begin{array}{l}\text { nd } \\
\text { nd } \\
\text { nd }\end{array}$ & $\begin{array}{r}8.5 \\
10.48 \\
5.4\end{array}$ \\
\hline
\end{tabular}

nd : not determined 


\section{References}

Alaoui-Mhamdi M., Aleya L. \& Bahhou J. 1996: - Nitrogen compounds and phosphate of the Driss I reservoir (Morocco) : imput, output and sedimentation. Hydrobiologia, $335: 75-82$.

An J. \& Carmichael W.W. 1994. - Use of colorimetric protein phosphate inhibition assay and enzyme linked immunosorbent assay for the study of microcystins and nodularins. Toxicon, 32 (12) : 1495-1507.

Anagnostidis K. \& Komarek J. 1988. - Modern approach to the classification system of cyanophytes. 3- Oscillatoriales. Arch. Hydrobiol. Suppl., 80 (1-4) (Algol. Studies 50-53) : 327-472.

Bouhaddioui A. 1997. - Bilans biogéochimiques de l'azote et du phosphore et dynamique des populations phytoplanctoniques de la retenue de barrage Allal El Fassi. Thèse $3^{\text {eme }}$ cycle, UniversitéSidi Med Ben Abdellah, Fès : $187 \mathrm{p}$.

Carmichael W.W. 1996. - Toxic Microcystis and the environment . In Toxic Microcystis. Watanabe, Harada \& Carmichael (eds) Publisher CRC Press. Chapter 1:1-11.

Cherifi O. \& Loudiki M. 1999. - Flood transport of dissolved and suspended matter in the El Abid river basin (Morocco). Hydrobiologia, 410 : 287-294.

Derraz M. 1995. - Etude de l'eutrophisation de la retenue du barrage El Kansera (Maroc). Thèse Doctorat es sciences, Université Moulay Ismail, Mèknès : $120 \mathrm{p}$.

Gayral P. 1954. - Recherches phytolimnologiques au Maroc. These de Doctorat es sciences, Université Paris : 301 p.

Ghedda K., Echihabi L., Foutlane A. \& Bouloud A. 1997. — Relation trophique et restauration de la qualité des eaux de la retenue Sahela utilisée pour l'alimentation en eau potable de la ville de Taounate (Maroc). Actes CILEF 5, Namur, Belgique.

Komarek J. \& Anagnostidis K. 1986. - Modern approach to the classification system of cyanophytes. 2- Chroococcales. Arch. Hydrobiol. Suppl., 73 (Algol. Studies, 43) : 157-226.

Kotai J. 1972. - Instructions for preparation of modified nutrient solution Z8 for algae. Norwegian institute for water research. Blindem. Oslo. B-11/69: 5 p.

Loudiki M. 1990. - Etude limnologique d'un hydrosystème recemment aménagé dans la région de Marrakech (Maroc). Thèse Doctorat es sciences, Université Aix-Marseille III : 353 p.

Loudiki M., Oudra B., Sbiyyaa B. \& Mouhri K 1995. - Inventaire et bioécologie des cyanobactéries toxiques occasionnant des blooms dans divers plans d'eau douce du Maroc. In Actes des Premières Journées Franco-Maghrébines sur les Phycotoxines. Université Hassan II, Casablanca.
Loudiki M., Sbiyyaa B. \& Oudra B. 1997. - Pluriannual dynamics and growth of Microcystis toxic population in hypertrophic Lalla Takerkoust reservoir (Morocco). VIII' ${ }^{\text {th }}$ International Conference on Harmful algae, Vigo, Spain.

Malki M. 1994. - Etude de la communauté phytoplanctonique et des caractéristiques physico-chimiques des eaux du lac réservoir $\mathrm{Al}$ Massira. Thèse Doctorat es sciences, Université Hassan II, Casablanca : $288 \mathrm{p}$.

Mouhri K. , Loudiki M., Le Cohu R. \& Zaki N., 1999. - Effet des enrichissements en nutriments sur le phytoplancton isolé à l'aide d'enceintes expérimentales placées in situ dans deux lacs réservoirs de la région de Marrakech (Maroc). Ann. Limnol., 35 (1) : 3-12.

ONEP 1996. - Les algues dans les retenues de barrage utilisées pour la production de l'eau potable au Maroc. Direction de contrôle de la qualitédes eaux, ONEP ed. : 105 p.

Oudra B., Loudiki M., Sbiyyaa B. \& Vasconcelos V. 1998. - Occurrence of hepatotoxic Microcystis aeruginosa water bloom in a eutrophic moroccan lake reservoir. In Harmful Algae, Reguera B., Blanco J., Fernandez M.L. \& Wyatt T. Xunta de Galicia and Intergovernmental Oceanographic Commission of Unesco : 29-31.

Oudra B., Loudiki M., Sbiyyaa B., Martins R., Vasconcelos V. \& Namikoshi N. 2001. - Isolation, characterization and quantification of microcystins in Microcystis aeruginosa dominated bloom of Lalla Takerkoust lake-reservoir (Morocco). Toxicon, 39 : 1375-1381.

Sabour B., Loudiki M., Oudra B., \& Oubraim S. 2002 - First results on Microcystis ichthyoblabe Kuitz. toxic bloom in hypertrophic oued Mellah lake (Morocco). Ann. Limnol., 38 (1) : 13-22.

Sbiyyaa B., Loudiki M. \& Oudra B. 1997. - Capacité de stockage intracellulaire de l'azote et du phosphore chez Microcystis aeruginosa Kütz. et Synechocystis sp. Cyanobactéries toxiques occasionnant des blooms dans la région de Marrakech. Ann. Limnol., 34 (3) : 247-257.

Starmach K. 1966. - Flora slodkowodna Polski, Tom 2, Cyanophyta. Sinice Glaucophyta, Glaukofity, Paustwowe wydawnictwonankowe : $806 \mathrm{p}$.

Watanabe M.F. \& Oishi S. 1985. - Effects of environmental factors on toxicity of a cyanobacterium Microcystis aeruginosa under culture conditions. Appl. Environ. Microbiol., 49 : 1342-1344.

Watanabe M.F. 1996. - Toxic Microcystis in eutrophic lakes. In Toxic Microcystis. Watanabe M.F., Harada K.-I. \& Carmichael W.W. (eds.), Publisher CRC Press : 57-77. 